\title{
Horticulture along the Blue Ridge
}

In Virginia, the Blue Ridge Mountains extend from the West Virginia border in the north to the North Carolina border in the southwest. The area is popular for summer recreation because of its natural beauty and close proximity to the major population centers of the mid-Atlantic region. Shenandoah National Park and the Blue Ridge Parkway, two of the most visited national parks in the United States, are located along the Blue Ridge.

The Blue Ridge region is also a major production area for a wide range of horticultural crops. Commercial cabbage production began in southwestern Virginia during the 1890s after the railroad linked Bristol, Term., with Roanoke, Va. The railroad enabled cabbage to be shipped to major metropolitan areas in the eastern United States, some as far away as New York City (Tobler, 1984). Cabbage grown further south along the North Carolina border was often transported by horse-drawn wagon to markets in nearby Mount Airy and Winston-Salem, N.C. With the introduction of trucks in the early 1900 s, distant markets became even more accessible. The cabbage industry grew and prospered following World War 1 (Delp, 1922). In addition to production for fresh market, cabbage was processed at a sauerkraut cannery in Crocket, Va. (Tobler, 1984). However, pest and disease problems, years of over-production, and the Great Depression lead to a reduction in cabbage production during the 1930s.

Today, $\approx 800$ ha of fresh-market cabbage are grown annually, primarily in the highlands along the Blue Ridge Mountains in Carroll, Patrick, and Floyd counties. Most cabbage is produced on a highland plateau north of the Blue Ridge at elevations from 650 to $1000 \mathrm{~m}$. Because of the elevation, temperatures are generally $\approx 5 \mathrm{C}$ cooler than in the adjacent Piedmont, a region of low, rolling hills throughout the southeastern United States that begins at the base of the mountains and extends south and east to the coastal plain. -Moderate temperatures, fertile soils, and frequent rainfall make the production of high-quality, coolseason vegetables possible throughout much of the summer and early fall.

Received for publication 19 June 1992. Accepted for publication 1 July 1992 . The cost of publishing this paper was defrayed in part by the payment of page charges. Under postal regulations, this paper therefore must be hereby markedadvertisement solely to indicate this fact.

Front cover Horticultural crops grown along the Blue Ridge Mountains in Virginia. (top left) Broccoli field, Carroll County. (bottom left) Apple orchard, Montgomery county. (right top to bottom) Fraser fir Christmas tree production. Vineyard,Naked Mountain. cabbage harvest, Carroll County. Photo credits: Greg Welbaum, Charles O'Dell, Robert Wright, and Tony Wolf.
As with" the cabbage industry, the peach and apple industries date back to the 19th century. In 1991, Virginia ranked sixth nationally in apple production and eleventh in peach production (Bass, 1992). Most apple and peach orchards are located in the Shenandoah Valley, west of the Blue Ridge, in northwestern Virginia. Significant apple and peach production areas also extend along the eastern slope of the Blue Ridge from northern Virginia to the North Carolina border.

Nursery crop production in Virginia is valued at more than $\$ 100$ million annually, placing the state among the top 20 producers nationally (Bass, 1992). Nursery stock and Christmas trees grown in the highlands west of the Blue Ridge are shipped throughout the eastern United States. Cut flowers are also grown in the region and shipped to markets in Virginia and North Carolina.

Virginia has a tradition of grape and wine production that dates back to colonial times. Thomas Jefferson established vineyards for wine production in western Virginia in the early 19th century using genotypes imported from Europe. The Blue Ridge region provides an excellent environment for quality wine production because of its unique climate. Today, several of Virginia's 45 wineries are located along the Blue Ridge.

Tobacco has traditionally been an important crop in the Blue Ridge region. Burley tobacco has been grown in the mountain valleys west of the Blue Ridge for generations. Flue-cured tobacco has been the predominant cash crop in the southern Piedmont region east of the Blue Ridge since colonial times. How- ever, the decline in tobacco consumption has generated considerable interest in alternative high-value crops that can be grown in the region.

Researchers and extension specialists from the Dept. of Horticulture at VirginiaTech have been working to diversify agriculture in the region by introducing profitable horticultural crops. Marketing studies have identified broccoli as a promising alternative crop for the area. Cabbage and broccoli production are similar in many respects; however, unlike cabbage, multiple broccoli florets may be harvested from a single plant. Several small florets are usually combined into a bunch before sale. The commercial production of bunching broccoli from direct-seeding has been successful in Virginia, with yields of $13,500 \mathrm{~kg} \cdot \mathrm{ha}^{-1}$ recorded in the state. In 1992, -250 ha of bunching broccoli was produced in Virginia, and it is anticipated that production area will continue to increase. However, Virginia Tech horticulturists have found that many consumers prefer large-head, single-stalk broccoli to bunching broccoli (Relf et al., 1990). Researchers and extension specialists in the department currently are working with the vegetable industry to increase single-stalk broccoli production to meet consumer demand.

Proper postharvest handling of broccoli is essential to maintain high quality. Broccoli is commonly packed in crushed ice to preserve freshness during shipment. However, crushed ice is expensive to produce, adds weight, and reduces the amount of broccoli that can be shipped. The waxed cardboard boxes used to ship iced broccoli have been banned in some areas due to environmental concerns, since they resist decomposition and are difficult to recycle. Shrink-film wrap, applied in conjunction with rapid cooling, retards deterioration

(continued on p. 687)

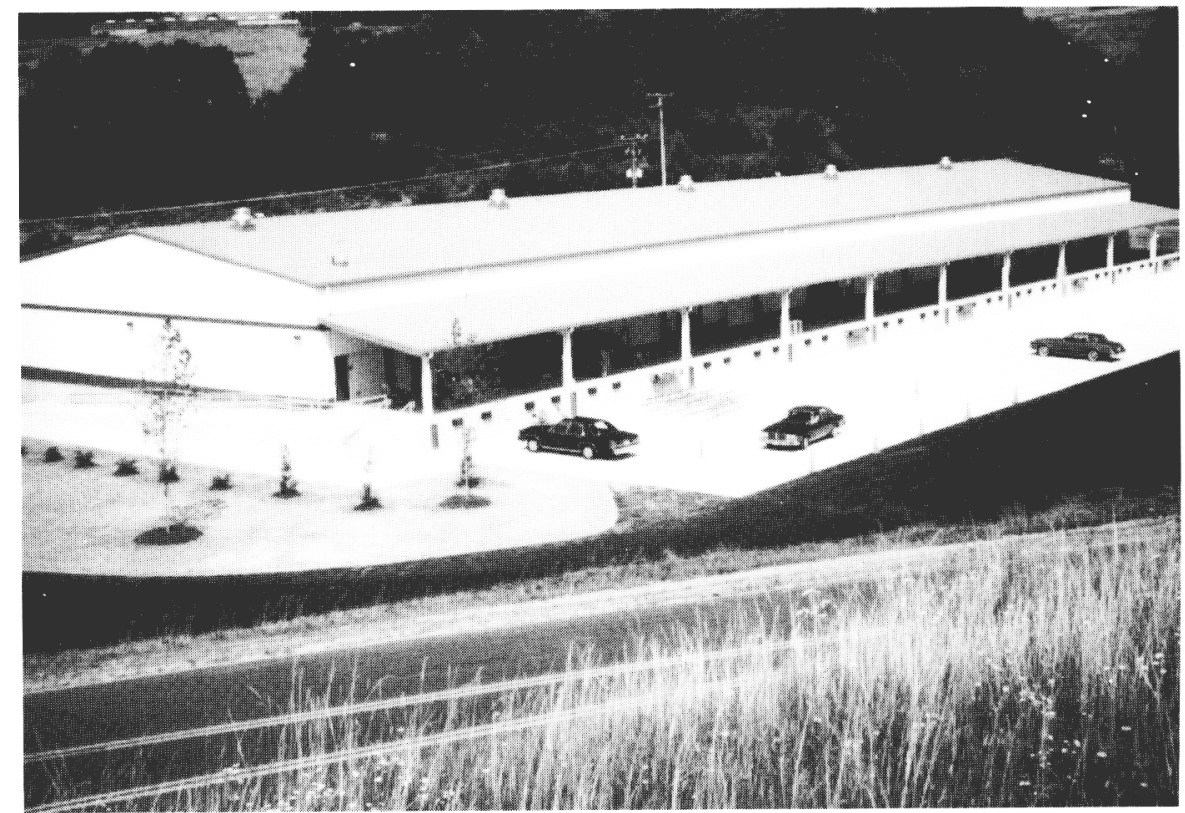

Fig. 1. Southwestern Virginia farmers' market, Hillsville, Va. 
of broccoli during storage and shipment without using ice (Forney and Rij, 1991). Studies at Virginia Tech have shown that consumer acceptance of shrink-wrapped broccoli is very favorable (Relf et al., 1990). Researchers at the university are studying whether shrink-film wrap can be used with innovative techniques for removing field heat to reduce handling costs and improve the quality of broccoli offered to the consumer.

The yellow-flesh, Irish potato has been a profitable alternative crop for the area (Morse et al., 1991). In 1992, Virginia-grown yellow-flesh potatoes were marketed under the 'Virginia Mountain Gold' label for the first time. These potatoes were well received at regional markets in Virginia and North Carolina.

Other research in the Dept. of Horticulture has identified cabbage cultivars that can be stored for up to 7 months with little quality loss (Welbaum, 1991). Using these cultivars, along with refrigerated storage facilities originally constructed for the apple industry, provides cabbage growers with an additional marketing option.
At Burkes Garden, Vs., a fertile plateau consisting of » 8000 ha of tillable land at a 1200-m elevation, extension specialists have produced cool-season crops such as cauliflower, broccoli, and lettuce throughout the summer months. It is hoped that alternative vegetable crops can substitute for less profitable agronomic crops that currently are grown in the area.

To improve the marketing of horticultural commodities, the Commonwealth of Virginia is constructing a network of five farmers' markets throughout the state. The first market began operation in Halifax in 1988. A second, a 9150- $\mathrm{m}^{2}$ produce market, opened in Hillsville in 1992 to serve growers in southwestern Virginia (Fig. 1). This market, located at the intersection of U.S. Route 58 and Interstate 77, a few miles north of the Blue Ridge Parkway, provides growers with a state-of-the-art marketing-both direct and wholesale-facility. Construction will begin on a third market in Accomack County on Virginia's eastern shore in 1993. For more information about the Virginia Farmers' Market Network, contact the Virginia Farmers' Market Board, P.O. Box 1163, Richmond, VA 23209; phone 804/ 371-6157.

\section{Literature Cited}

Bass, R.T. 1992. Virginia agricultural statistics 1991. Virginia Agr. Stat. Serv. Bul. 63.

Tobler, V.H. 1984. Carroll County memories 18901920. Presgaves, Wytheville, Va.

Delp, J.E. 1922. Extension division news. Virginia Polytechnic Inst. Coop. Ext. IV(4):2.

Forney, C.F. and R.E. Rij. 1991. Temperature of broccoli florets at time of packaging influences package atmosphere and quality. HortScience 26:1301-1303

Morse, R.D., J. Okeyo, M.M. Kushad, and C.R. O'Dell. 1991. Postharvest quality of single unit broccoli. HortScience 26:775. (Abstr.)

Relf, D., C. O’Dell, and M. Kushad. 1990. Virginia Master Gardeners reveal preferences in broccoli survey. HortScienee 25:706.

Welbaum, G.E. 1991. Storage cabbage as an alternative crop for southwest Virginia. HortScience 26:91. (Abstr.)

Gregory E. Welbaum, Charlie R. O'Dell and Ronald D. Morse Dept. of Horticulture Virginia Polytechnic Inst. and State Univ. Blacksburg, VA 24061-0327 